\title{
STRATEGI PEMERINTAH DESA DALAM MENINGKATKAN KESADARAN MASYARAKAT DALAM MEMBAYAR PAJAK BUMI DAN BANGUNAN
}

\author{
Miko Nugroho, Eny Kusdarini \\ Program Studi Magister Pendidikan Pancasila dan Kewarganegaraan \\ Universitas Negeri Yogyakarta \\ Jl. Colombo No. 1, Sleman, Daerah Istimewa Yogyakarta \\ Email: miko.nugroho2016@student.uny.ac.id
}

\begin{abstract}
Government of Kliwonan Village, Banyuurip District, Purworejo Regency to increase public awareness in paying for land and building taxes. This study uses a qualitative approach with a descriptive research type. Purposive sampling used to determine the informant. Observation, interviews, and documentation used for collecting data. This study shows the strategy undertaken by the government is collaborating with the Banyuurip District Government, optimizing all village officials, mobilizing PKK and Dasa Wisma Mobilization Teams, conducting socialization, and visiting taxpayers directly.
\end{abstract}

Keywords: strategy, village goverment, land and building tax

\begin{abstract}
Abstrak: Tulisan ini bertujuan untuk mengungkapkan strategi Pemerintah Desa Kliwonan Kecamatan Banyuurip Kabupaten Purworejo untuk meningkatkan kesadaran masyarakat dalam membayar pajak bumi dan bangunan. Penelitian ini menggunakan pendekatan kualitatif dengan jenis penelitian deskriptif. Teknik penentuan informan yang digunakan dalam penelitian ini adalah purposive sampling. Teknik pengumpulan data yang digunakan dalam penelitian ini adalah observasi, wawancara, dan dokumentasi. Kajian ini menunjukkan bahwa strategi yang dilakukan oleh pemerintah adalah bekerjasama dengan Pemerintah Kecamatan Banyuurip, mengoptimalkan seluruh perangkat desa, menggerakkan Tim Penggerak PKK dan Dasa Wisma, melaksanakan sosialisasi, dan mendatangi langsung wajib pajak.
\end{abstract}

Kata Kunci: strategi, pemerintah desa, pajak bumi dan bangunan (PBB)

\section{PENDAHULUAN}

Pembangunan sangat penting bagi keberlangsungan kehidupan berbangsa dan bernegara. Sumber dana pembangunan dapat diperoleh dari sumber daya alam (SDA), aktivitas usaha pemerintah (BUMN/ BUMD), pinjaman, hibah, dan pajak. Sumbersumber tersebut, sektor pajak merupakan penyumbang pemasukan negara yang paling besar, karena pajak merupakan sumber yang sangat penting karena melibatkan partisipasi warga negara untuk pembangunan, baik fisik maupun non fisik demi terwujudnya negara kesejahteraan Indonesia.

Laporan yang disusun oleh Direktorat Penyusunan APBN, Direktorat Jenderal Anggaran, Kementrian Keuangan Republik
Indonesia jumlah penerimaan negara tahun 2016 sebesar Rp1.822,5 triliun. Jumlah ini terdiri atas penerimaan perpajakan sebesar Rp1.360,2 triliun atau sebesar 75\% dari total pendapatan negara, penerimaan negara bukan pajak (PNBP) sebesar Rp273,8 triliun hanya sebesar $15 \%$ saja dari penerimaan negara, sedangkan dari pemasukan cukai dan hibah hanya memberikan tambahan kepada penerimaan negara sebesar 10\%. Hal ini memperlihatkan betapa besarnya penerimaan negara dari sektor perpajakan. (Kementrian Keuangan: 2016)

Dalam postur APBN 2017 ditetapkan jumlah pendapatan negara sebesar Rp1.750,3 triliun. Jumlah ini terdiri dari penerimaan 
perpajakan sebesar Rp1.489,9 triliun atau $85,6 \%$, penerimaan negara bukan pajak (PNBP) sebesar Rp250 triliun atau 14,3\%, dan penerimaan hibah sebesar Rp1,4 triliun atau $0,1 \%$. Keadaan ini menggambarkan pentingnya penerimaan negara disektor pajak, pajak menopang jalannya roda pemerintahan. Oleh karena itu, setiap tahun penerimaan pajak menjadi sumber pendapatan negara yang paling utama untuk penyokong roda pemerintahan (Kementrian Keuangan: 2017)

Penerimaan yang berasal dari sektor pajak juga dapat menjadi prosedur untuk digunakan menopang kedaulatan rakyat dalam pelaksanaannya, kedaulatan negara dapat diartikan secara global, sebagai wujud kemampuan negara dalam mengelola negaranya tanpa campur tangan pihak manapun. Sedangkan, konsep negara didasarkan pada wilayah, warga negara dan pemerintahan yang diakui oleh semua warga negara secara hukum.

Warga negara hendaknya menyadari akan kewajibannya terhadap negara, yaitu salah satunya dengan membayar pajak. Kesadaran untuk menjadi wajib pajak dengan memenuhi segala kewajibannya perlu dibina dan ditanamkan bagi rakyat Indonesia. Adanya kesadaran warga negara dalam membayar pajak akan memperlancar roda pemerintahan, lancarnya roda pemerintahan akan melancarkan pula tercapainya keseluruhan cita-cita rakyat yang hidup dalam negara yang adil dan makmur. Akan tetapi sampai saat ini masih banyak rakyat Indonesia yang belum sadar akan kewajiban membayar pajak.

Berdasarkan laporan dari CNN pada tahun 2016 belum menembus separuh dari target. Penerimaan pajak melaporkan sampai 13 September 2016 realisasi penerimaan pajak baru mencapai $\mathrm{Rp} 656,11$ triliun atau 48,41 persen dari target $\mathrm{Rp} 1.355,2$ triliun (Primadhyta: 2016). Untuk dapat terlaksananya pembangunan dan penyelenggaraan negara dibutuhkan suatu kerjasama antara masyarakat dengan pemerintah. Masyarakat menaati dan melakukan kewajiban sebagai warga negara. Sedangkan pemerintah berkewajiban memberikan pelayanan kepada masyarakat atau wajib pajak dengan baik.

Masyarakat mengharapkan uang yang diberikan kepada negara dapat digunakan dengan sebaik-baiknya oleh pemerintah untuk kemajuan negara dan kesejahteraan rakyat. Masyarakat ingin melihat jelas apa yang dilakukan oleh pemerintah dengan uang pembayaran pajak dari rakyat betulbetul di gunakan demi kesejahteraan rakyat. Kenyataan yang dialami selama ini, sering terjadi para pejabat tinggi pemerintah yang melakukan korupsi uang rakyat untuk kepentingan pribadi. Berdasarkan laporan kompas.com terjadi kasus pegawai pajak yang diperkarakan kepengadilan dan didakwa menerima suap sebesar 148.500 dollar AS atau senilai Rp 1,9 miliar (Gabrillian: 2017). Kejadian ini semakin membuat masyarakat mempertanyakan manfaat dari membayar pajak kalau ujung-ujungnya uang tersebut tidak tepat penggunaannya. Korupsi yang dilakukan oleh pejabat adalah salah satu pemicu kurangnya keyakinan dan kesadaran masyarakat dalam memenuhi kewajibannya sebagai warga negara Indonesia.

Masyarakat dituntut oleh pemerintah sebagai penyelenggara negara untuk patuh terhadap peraturan. Dalam hal ini peraturan membayar pajak bumi dan bangunan tapi disisi lain pemerintah sendiri dalam hal ini yang melakukan kecurangan seperti korupsi dan menerima suap. Melihat fenomena ini bukan saja penyimpangan terjadi di dalam masyarakat tetapi jugadidalam tubuh aparat pemerintah.Sehingga perlu dilakukan perbaikan juga kepada aparat pemerintah agar pemerintah danmasyarakat dapat berjalan lurus. Berdasarkan penelitian Supadmi (2009:14), tentang peningkatan kepatuhan wajib pajak, untuk meningkatkan kepatuhan wajib pajak dalam memenuhi kewajiban perpajakan kualitas pelayanan harus ditingkatkan oleh aparat pajak. Pelayanan yang berkualitas harus diupayakan 
dapat memberikan 4K yaitu keamanan, kenyamanan, kelancaran, dan kepastian hukum.

Pembangunan dan penyelenggaraan negara dibutuhkan suatu kerjasama antara masyarakat dengan pemerintah. Masyarakat menaati dan melakukan kewajiban sebagai warga negara. Sedangkan, pemerintah berkewajiban memberikan pelayanan kepada masyarakat atau wajib pajak dengan baik. Menurut Branson (1999:30) tangungjawab kewarganegaraan seperti taat pada hukum, memiliki kepekaan dan mengikuti perkembangan isu-isu publik, memegang kendali kepemimpinan bila diperlukan, membayar pajak, menjadi relawan dalam angkatan bersenjata serta melakukan pelayanan masyarakat. Pengajaran tentang tanggung jawab hendaknya menegaskan bahwa antara hak-hak dan tanggungjawab haruslah berjalan secara bersamaan.

Berdasarkan kewenangan pemungutan pajak, di Indonesia pajak dapat dibagi menjadi pajak pusat dan pajak daerah (Muljono,2010: 17). Pajak pusat merupakan pajak yang pemungutan dan pengelolaannya dilakukan oleh pemerintah pusat. Sedangkan pajak daerah merupakan pajak yang dikelola oleh pemerintah daerah baik provinsi maupun kabupaten atau kota yang berguna untuk menunjang penerimaan pendapatan asli daerah. Salah satu jenis pajak daerah yang dikelolah oleh kabupaten atau kota adalah pajak bumi dan bangunan, yang merupakan pajak atas tanah dan bangunan, baik yang dimiliki, diperoleh kemanfaatannya maupun dikuasai oleh orang atau badan. Dasar hukum terkait pajak bumi dan bangunan adalah Undang-Undang Nomor 12 Tahun 1985 yang telah diubah menjadi Undang-Undang Nomor 12 Tahun 1994 dan yang terakhir adalah Undang-Undang No. 28 Tahun 2009 tentang Pajak Bumi dan Bangunan.

Kanian ini akan memfokuskan pada pengkajian tentang Pajak Bumi dan Bangunan (PBB) karena setiap warga negara berkewajiban untuk membayar PBB bagi yang memiliki dan/atau mendapat manfaat dari bumi dan bangunan (Isnanto, 2014: 9). Kesadaran akan kewajiban membayar pajak merupakan salah satu kajian pendidikan kewarganegaraan dalam membangun tangungjawab warga negara dalam melaksanakan kewajiban sebagai seorang warga negara. Kajian kewarganegaraan tidak hanya membahas tentang hak warga negara akan tetapi mengkaji tentang upaya-upaya pemerintah dalam membangun tangung jawab warga negara untuk berpartisipasi aktif dalam membangun negara melalui membayar pajak.

Pendidikan kewarganegaraan bertujuan untuk melaksanakan cita-cita negara demokratis yakni untuk mewujudkan warganegara aktif terlibat dalam pemerintahannya sendiri, mereka tidak didikte orang lain atau memenuhi tuntutan orang lain dengan kata lain, cita-cita demokrasi dapat diwujudkan dengan sesunggunya bila setiap warganegara dapat berpartisipasi dalam pemerintahannya (Branson, 1999:4-5).

Berdasarkan laporan hasil penelitian yang dilakukan oleh Lestari, (2017:12) dengan judul penelitian Analisis Penerimaan Pajak Bumi dan Bangunan Perdesaan dan Perkotaan (PBB-P2) di Kabupaten Purworejo (studi kasus tahun anggaran 2013-2016), menunjukan hasil pertama, perlu adanya peningkatan kinerja dari petugas pemungut pajak supaya hambatan yang mempengaruhi penerimaan pajak dapat diminimalisir. Kedua, perlunya melakukan sosialisasi, pendataan ulang, pemilihan wajib pajak teladan dan memberikan keringanan bagi wajib pajak yang penunggakan pembayaran pajak. Ketiga, pajak bumi dan bangunan masih menjadi andalan pendapatan daerah yang cukup besar berkontribusi penompang pembangunan di Kabupaten Purworejo dibandingkan dengan pajak lainnya.

Kesadaran masyarakat Purworejo dalam membayar Pajak Bumi dan Bangunan (PBB) masih cukup rendah, terutama di kecamatan Banyuurip dan Purwodadi (Ansori, 2017). 
Pada tahun 2013 hingga 2016 kemarin, di Kabupaten Purworejo tunggakan PBB sangat tinggi hingga mencapai 147.860 objek pajak yang tersebar di 123 desa dari 14 Kecamatan. Nilai total pajak yang masih tertunggak hingga kini mencapai kurang lebih Rp 5 miliar.

Penerimaan PBB dari tahun 2013-2016 Kabupaten Purworejo, Kecamatan Banyuurip menjadi kecamatan yang memperoleh persentase penerimaan Pajak Bumi dan Bangunan yang paling rendah dari enam belas kecamatan sekabupaten Purworejo.
Kecamatan Banyuurip mendapat persentase total rata-rata dari tahun 2013-2016 hanya $87.51 \%$ yang menempatkannya berada di tingkat penerimaan PBB paling rendah. Kecamatan Banyuurip terdapat 27 desa dan kelurahan se Kecamatan Banyuurip, dari sekian banyak desa dan kelurahan yang tersebar terdapat satu desa yang persentase penerimaan pajak bumi dan bangunan yang paling rendah yaitu berada di Desa Kliwonan, untuk lebih jelas data persentase penerimaan PBB di Desa Kliwonan dapat dilihat pada tabel 1.1. berikut:

Tabel.1.1 Data Persentase Penerimaan PBB Desa Kliwonan Tahun 2013-2017

\begin{tabular}{ccccc}
\hline TAHUN & $\begin{array}{c}\text { KETETAPAN } \\
\text { POKOK }\end{array}$ & $\begin{array}{c}\text { JUMLAH } \\
\text { SPPT }\end{array}$ & $\begin{array}{c}\text { REALISASI } \\
\text { POKOK }\end{array}$ & PERSENTASE \\
\hline 2013 & $38,681,940$ & 1,534 & $19,688,255$ & $50,89 \%$ \\
2014 & $38,675,282$ & 1,534 & $25,682,748$ & $66,40 \%$ \\
2015 & $38,802,862$ & 1,534 & $31,239,569$ & $80,50 \%$ \\
2016 & $39,358,890$ & 1,563 & $30,163,203$ & $76,63 \%$ \\
2017 & $52,208,752$ & 1,536 & $31,647,889$ & $60,61 \%$ \\
\hline
\end{tabular}

Sumber: Data diolah dari laporan PBB Kecamatan Banyuurip.

Pada tahun 2013 pajak bumi dan bangunan awal pertama kali di serahkan pemungutannya kepada pemerintah daerah, pemerintah desa merupakan bagian yang langsung bersentuhan kepada wajib pajak di paling bawah, di Desa Kliwonan pada tahun 2013 penerimaan PBB hanya mencapai 50,89 $\%$ dari reaslisasi PBB, terjadi peningkatan sebanyak $16 \%$ pada tahun 2014 dan terjadi peningkatan penerimaan PBB yang drastis di atas tahun 2015 yaitu $80,50 \%$ persentase penerimaan PBB sedangkan pada tahun 2016 terjadi penurunan penerimaan $\mathrm{PBB}$ yaitu $76,63 \%$ dapat dilihat pada tabel 1.2 pada tahun 2017 penerimaan PBB di Desa Kliwonan terjadi penurunan yang cukup drastis penerimaan $\mathrm{PBB}$ hanya mencapai $60,61 \%$. Dari tabel diatas dapat disimpulkan bahwa dua tahun terakhir penerimaan PBB di Desa Kliwonan mengalami penurunan.

Pemerintah Desa Kliwonan Kecamatan Banyuurip pada tanggal 11 Desember
2017 terjadi pergantian kepala desa setelah sebelumnya dilakukan pemilihan kepala desa secara langsung oleh masyarakat Desa Kliwonan. kepala desa yang baru dilantik pada Desember 2017 ini mendapat amanah untuk memperbaiki penerimaan PBB di Desa Kliwonan melalui kebijakan-kebijakan yang dibuat agar penerimaan PBB dapat diterima secara maksimal. Oleh karena itu penting melihat strategi pemerintah Desa Kliwonan dalam meningkatkan kesadaran masyarakat membayar pajak bumi dan banguanan. Dalam konteks ini, masyarakat yang dimaksud adalah pihak yang memiliki tanah dan bangunan dan berkewajiban membayar pajak bumi dan bangunan. Selanjutnya, pihak yang memiliki tanah dan bangunan disebut sebagai wajib pajak.

\section{METODE}

Artikel ini menggunakan metode deskriptif kualitatif untuk mendeskripsikan 
strategi Pemerintah Desa Kliwonan untuk meningkatkan kesadaran masyarakat membayar pajak bumi dan bangunan (PBB). Sebagaimana diungkapkan Moleong (2007:6) kajian kualitatif berusaha memahami fenomena tentang apa yang dialami oleh subjek kajian misalnya menyangkut perilaku, persepsi, motivasi, tindakan secara holistik.

Pengumpulan data dilakukan dengan menggunakan wawancara, observasi, dan dokumen. data yang diperoleh melalui wawancara merupakan data primer sedangkan data yang diperoleh dari observasi dan dokumen meupakan data sekunder. Penentuan subjek menggunakan teknik purposive, antara lain 1) Sekertaris Camat selaku Koordinator Tim Intensifikasi PBB Kecamatan; 2) Kepala Desa Kliwonan; 3) Koordinator Tim Intensifikasi PBBDesa; 4) KAUR Kesejahteraan Rakyat; 5) PLT Sekertaris Desa; 6) Kepala Dusun I; 7) Kepala Dusun II; 8) Ketua Tim Penggerak PKK Desa Kliwonan; 9) Ketua Kelompok Dasa Wisma.

\section{HASIL DAN PEMBAHASAN}

\section{Strategi Pemerintah Desa Untuk Meningkatkan Kesadaran Masyarakat dalam Membayar Pajak Bumi Dan Bangunan (PBB)}

Pajak memiliki peran penting dalam proses pembangunan bangsa yang berkelanjutan. Hal ini dikarenakan hasil dari penarikan pajak yang dilakukan oleh pemerintah diperuntukan untuk pembangunan dalam setiap bidang mulai dari pembangunan fisik maupun non fisik. Beberapa sumber yang diperlukan untuk pembangunan bangsa dan negara dapat diperoleh dari berbagaimacam cara, salah satunya adalah pajak. Setiap warga negara yang menjadi subyek pajak memiliki kewajiban untuk membayar pajak sesuai dengan Undang-undang yang berlaku. Kesadaran masyarakat dalam membayar pajak harus terus ditingkatkan untuk mengoptimalkan pendapatan pajak demi mewujudkan negara yang sejahtera adil dan makmur. Setiap pemerintah mulai dari pusat sampai tingkat desa harus ikut berperan dalam upaya tersebut. Hal ini yang membuat Pemerintah Desa Kliwonan, Kecamatan Banyuurip, Kabupaten Purworejo melakukan beberapa strategi untuk meningkatkan kesadaran masyarakatnya dalam kewajiban membayar Pajak Bumi dan Bangunan (PBB). Strategi yang dilakukan Pemerintah Desa Kliwonan, Kecamatan Banyuurip, Kabupaten Purworejo untuk meningkatkan kesadaran masyarakat dalam membayar Pajak Bumi dan Bangunan (PBB) melalui 5 cara, yaitu: bekerjasama dengan pemerintah kecamatan, mengoptimalkan seluruh perangkat desa, menggerakan tim PKK dan dasa wisma, melaksanakan sosialisasi, mendatangi langsung wajib pajak.

\section{Bekerjasama dengan Pemerintah Kecamatan Banyuurip}

Isett et al. (2011: 161) membedakan antara tiga jaringan manajemen publik yang terpisah: jaringan kebijakan, kolaborasi dan tata kelola, jaringan kebijakan berusaha untuk membentuk pengambilan keputusan publik, jaringan kolaboratif bekerja sama dalam penyampaian layanan dan jaringan tata kelola menggabungkan aspek pembuatan kebijakan. Abdulsyani (2012: 156) menjelaskan kerjasama merupakan suatu bentuk proses sosial yang didalamnya terdapat aktivitas tertentu yang ditujukkan untuk mencapai tujuan bersama dengan saling memahami dan saling membantu terhadap aktivitas masing-masing.

Kerjasama merupakan suatu proses sosial yang paling dasar Kerjasama timbul apabila orang mulai menyadari bahwa mereka mempunyai kepentingan-kepentingan yang sama dan pada saat yang bersamaan mempunyai cukup pengetahuan dan pengendalian terhadap diri sendiri untuk memenuhi kepentingan tersebut melalui kerjasama. Sehingga dapat disimpulkan kerjasama adalah suatu bentuk proses yang di dalamnya terdapat aktifitas yang dilakukan oleh beberapa orang/kelompok 
yang ditujukkan guna mencapai tujuan bersama dengan saling membantu dan saling memahami terhadap kegiatan masing-masing.

Bekerjasama dengan pemerintah kecamatan dilakukan oleh Pemerintah Desa Kliwonan untuk mencapai tujuan bersama yaitu, tercapainya kesadaran wajib pajak dalam membayar pajak bumi dan bangunan (PBB) di Desa Kliwonan Kecamatan Banyuurip. pemerintah desa dan pemerintah kecamatan menjalannkan tugasnya sebagai manajemen publik yaitu jaringan kebijakan, kolaborasi dan tata kelola.

\section{Mengoptimalkan Seluruh Perangkat Desa}

Hasil penelitian Bucek (2017:33), menjelaskan bahwa reformasi administrasi publik merupakan salah satu ekspresi yang paling khas dalam kemajuan masyarakat dari sudut pandang pemerintah dan sektor publik. Reformasi memiliki peluang yang baik jika pemerintah dan elit politik yang stabil. Ada faktor yang berpengaruh dalam jangka waktu tertentu pada kasus transisi administrasi dan warisan kebijakan. Pergantian Pemerintahan Desa Kliwonan mengharuskan adanya reformasi administrasi publik dibidang pajak. Kepala Desa Kliwonan yang terpilih telah melakukan reformasi dibidang administrasi pajak bumi dan bangunan dengan cara mengoptimalkan seluruh Perangkat Desa Kliwonan dalam peningkatan kesadaran masyarakat membayar PBB.

Clutterbuck (2007: 38-39) menjelaskan pentingnya sebuah kerjasama tim adalah membawa sesuatu yang ekstra pada sifat dan kualitas interaksi antara anggota kelompok. Semakin banyak orang yang terlibat, semakin kompleks interaksi, kelompok yang kurang mampu dalam melaksanakan tugas akan berfungsi dengan baik. Dengan kata lain kerjasama tim adalah sekelompok orang yang saling membantu sehubungan dengan informasi, sumber daya, dan keterampilan untuk mencapai tujuan bersama. Hackman mendefinisikan tim (Clutterbuck, 2007:40) dengan menyatakan bahwa kerjasama tim ada untuk mencapai tujuan bersama, anggota tim bergantung satu sama lain untuk mencapai tujuan, mereka memiliki batasan (siapa yang ada di tim dan siapa yang tidak), mereka stabil dari waktu ke waktu, mereka memiliki wewenang untuk mengelola pekerjaan mereka sendiri dan proses internal, dan kerjasama tim beroperasi dalam konteks sistem sosial.

Program untuk pemungutan pajak yang dilakukan oleh kepala desa merupakan kerjasama tim yang mengharuskan seluruh perangkat desa terlibat dalam pemungutan pajak. Kendala yang dulu hanya di alami oleh tim pemungut (kepala dusun) dengan kebijakan baru Kepala Desa Kliwonan tersebut kendala tersebut dialami bersama dan dapat di atasi oleh tim dengan bergabungnya seluruh Perangkat Desa melaksanakan pemungutan menjadi lebih ringan dan efektif.

Heifetz \& Linsky (2002: 73) menangkap tanggung jawab pemimpin adalah seni improvisasi. Pemimpin memiliki visi yang jelas, mengorientasikan nilai-nilai, dan bahkan membuat rencana strategis yang dilakukan dari waktu ke waktu. Pemimpin mengambil tindakan dan menilai hasil dari tindakan untuk membuat langkah selanjutnya. Senada dengan peryataan di atas, Kepala Desa Kliwonan selaku pimpinan di tingkat desa telah membuat rencana strategis dengan mengoptimalkan seluruh perangkat desa dalam kegiatan peningkatan kesadaran masyarakat wajib pajak dalam membayar Pajak Bumi dan Bangunan.

Anggota tim selalu bertanggungjawab untuk melaksanakan tugas, kepala desa tidak dapat melakukan pemantauan dan pengelolaan proses kerjasama tim, merancang cara fungsi kelompok, dan merancang bagaimana kelompok tim berinteraksi dengan organisasi yang lebih luas. Dalam kerjasama tim pemungutan pajak yang dipimpin oleh kepala desa, kepala desa memutuskan apa tujuan dan bagaimana struktur tim pemungutan pajak, pemungutan pajak bertanggungjawab agar mencapai 
tujuan yaitu tercapainya target dalam penerimaan Pajak Bumi dan Bangunan dari wajib pajak di Desa Kliwonan.

\section{Menggerakan Tim PKK Dan Dasa Wisma}

Clutterbuck (2007: 56) menjelaskan salah satu yang dapat meningkatkan tim menjadi efektif adalah seberapa beragam anggota tim. Kemampuan yang beragam membuat keputusan lebih inovatif dan berkualitas dari pada yang relatif homogeny. Menggunakan keragaman, lebih efektif dalam pengambilan keputusan. Tim memiliki proses yang memungkinkan anggotanya untuk memiliki dialog terbuka dan positif serta kritis, untuk pemecahan masalah dengan pikiran terbuka dan bersedia untuk belajar dari situasi dan dari satu sama lain. Mereka juga harus mampu mengidentifikasi dan memahami perspektif orang lain dan mensintesakan menjadi keputusan yang lebih baik dari apa yang mungkin telah muncul melalui kompromi yang menarik beberapa benang merah dan perspektif untuk menciptakan pilihan yang lebih luas dan evaluasi resiko dan manfaat yang lebih akurat. Pengambilan keputusan ini tidak bernilai kecuali didukung oleh konsensus diantara anggota tim berkaitan dengan apa arti keputusan dan komitmen yang diperlukan baik secara individu maupun bersama-sama. Pengembangan pemahaman dan komitmen perlu terjadi ketika keputusan sedang dibuat.

Menggerakan Tim Pemberdayaan dan Kesejahteraan Keluarga (PKK) dan Dasawisma merupakan kebijakan yang membuat tim pemungutan pajak lebih beragam. Tim pemungutan pajak yang dulunya hanya dilakukan oleh kepala dusun menjadi lebih beragam dengan adanya kebijakan dari kepala desa mengikut sertakan TP PKK dan Dasawisma dalam kegiatan peningkatan kesadaran wajib pajak dalam membayar Pajak Bumi dan Bangunan.

Tim Penggerak Pemberdayaan dan Kesejahteraan Keluarga (TP PKK) merupakan gerakan paling terendah dan bermanfaat bagi masyarakat terutama di daerah pedesaan. Gerakan yang dimotori oleh perempuan mempunyai andil besar dalam membentuk sebuah keluarga yang bermartabat. Perempuan juga mempunyai andil besar dalam kegiatan penanggulangan kemiskinan melalui pemberdayaan masyarakat dan kelompok yaitu dengan pendidikan dan keterampilan yang dimiliki. Untuk dapat membina keluarga secara langsung dan menjangkau sasaran sebanyak mungkin, maka dibentuk Tim Penggerak Pemberdayaan dan Kesejahteraan Keluarga (TP PKK), yang mekanisme gerakannya dikelola dan dilaksanakan oleh suatu Tim Penggerak Pemberdayaan dan Kesejahteraan Keluarga di setiap jenjang.

Hasil penelitian Riana, Sjamsuddin, dan Hayat (2014: 851-856) menunjukkan bahwa Pelaksanaan Peran tim penggerak Pemberdayaan dan Kesejahteraan Keluarga (PKK) khususnya program pendidikan dan keterampilan sudah terlaksana dan berjalan dengan baik. Peranan dari tim penggerak Pemberdayaan dan Kesejahteraan Keluarga (PKK) dapat menggugah masyarakat agar termotivasi untuk selalu dinamis, dapat mengubah keadaan kearah yang lebih maju dan manfaatnya telah dirasakan oleh masyarakat. Adanya pemberdayaan dari tim penggerak Pemberdayaan dan Kesejahteraan Keluarga (PKK) dapat meningkatkan peran dan pemberdayaan perempuan dalam pembangunan. Berdasarkan hasil penelitian Wati, Suntoro, dan Yanzi (2015: 1-12), dapat disimpulkan bahwa Pemberdayaan dan Kesejahteraan Keluarga (PKK) memiliki peranan yang cukup besar dalam meningkatan pemberdayaan wanita. Peranan Pemberdayaan dan Kesejahteraan Keluarga (PKK) tersebut meliputi: Pertama, meningkatkan pendidikan dan ketrampilan, Kedua, meningkatkan kualitas dan kuantitas pangan keluarga, dan Ketiga, meningkatkan derajat kesehatan.

Peranan Tim Penggerak Pemberdayaan 
dan Kesejahteraan Keluarga (TP PKK) merupakan salah satu organisasi yang telah ada dan diakui manfaatnya bagi masyarakat, terutama dalam upaya meningkatkan keberdayaan dan kesejahteraan keluarga adalah gerakan Pemberdayaan dan Kesejahteraan Keluarga (PKK). Pemberdayaan dan Kesejahteraan Keluarga (PKK) merupakan suatu gerakan yang di bentuk untuk menggerakkan partisipasi masyarakat dan memberdayakan guna untuk mewujudkan pembangunan di desa. Posisi atau kedudukan PKK dalam masyarakat cukup penting karena berusaha untuk menggerakkan partisipasi masyarakat dan berusaha memenuhi kebutuhan masyarakat untuk mewujudkan pembangunan di desa dan meningkatkan kesejahteraan keluarga (Rantung, Mandey, dan Londa, 2014: 1-11).

Kesejahteraan keluarga menjadi tujuan utama Pemberdayaan dan Kesejahteraan Keluarga (PKK). Dari keluarga yang sejahtera ini, maka akan terwujud tata kehidupan berbangsa dan bernegara yang akan dapat melahirkan ketentraman, keamanan, keharmonisan, dan kedamaian. Oleh karena itu, kesejahteraan keluarga menjadi salah satu tolak ukur dan barometer dalam pembangunan dengan programprogram pemerintah. Pemberdayaan dan Kesejahteraan Keluarga (PKK) merupakan gerakan untuk membantu dan mendukung program-program pemerintah dengan mendata beberapa aspek yang diperlukan seperti data warga, ibu hamil, bayi, kelahiran, dan kematian, sampai kegiatan masyarakat. Salah satu program dari Pemberdayaan dan Kesejahteraan Keluarga (PKK) di Desa Kliwonan adalah membantu ikut serta dalam optimalisasi peningkatan kesadaran pembayaran pajak bumi dan bangunan oleh wajib pajak di Desa Kliwonan.

Strategi yang dilakukan oleh Pemerintah Desa Kliwonan dalam pengoptimalan kesadaran pembayaran pajak selain menggerakkan PKK adalah Dasa Wisma. Hasil penelitian Wafiyah (2015: 145-175) menunjukkan bahwa Dasa Wisma sebagai obyek pembinaan gerakan PKK memiliki banyak manfaat. Pemberdayaan Dasa Wisma sebagai upaya keberlangsungan kebersihan, keindahan, dan ketertiban di desa. Keluarga adalah unit terkecil dalam sebuah masyarakat Rukun Tetangga (RT), merupakan obyek pembinaan gerakan PKK (Pembinaan Kesejahteraan Keluarga). Sebagai obyek pembinaan gerakan PKK, keluarga dikelompokan menjadi beberapa Dasa Wisma. Secara terminologi, dasa berarti sepuluh, dan wisma berarti rumah. Dasa Wisma berarti sepuluh rumah. Secara etimologi, Dasa Wisma adalah sekelompok komunitas ibu-ibu yang terdiri dari sepuluh keluarga atau sekelompok komunitas ibuibu dalam suatu RT.

Dasa Wisma sebagai kelompok terkecil dari kelompok-kelompok PKK memiliki peran strategis mewujudkan keluarga sejahtera. Untuk itu, di harapkan agar Dasa Wisma menjadi ujung tombak pelaksanaan 10 program pokok PKK dan program pemerintah karena sebagai mitra. Selain itu, melalui dasa wisma diharapkan dapat memantau sekaliguspengoptimalan kesadaran pembayaran pajak bumi dan bangunan. Kegiatan dasa wisma di Desa Kliwonan kelompok Dasa Wisma bukan hanya kegiatan dalam pemberdayaan dan peningkatan kesejahteraan masyarakat saja, kelompok Dasa Wisma ikut serta berperan membantu pemerintah Desa Kliwonan dalam meningkatkan kesadaran masyarakat wajib pajak PBB di Desa Kliwonan dengan memberdayakan ibuibu dan selalu meyuarakan dan mengajak supaya membayar PBB tepat waktu.

\section{Melaksanakan Sosialisasi}

Kepatuhan membayar pajak bumi dan bangunan dipengaruhi oleh berbagai faktor, antara lain faktor sosialisasi. Adanya sosialisasi, diharapkan kepatuhan wajib pajak dapat timbul dari diri wajib pajak. Sosialisasi merupakan salah satu cara atau alat yang dapat digunakan untuk 
mengguggah dan memberikan pengetahuan kepada para wajib pajak tentang Peraturan, tata cara perpajakan, prosedur, serta waktu pembayaran Pajak Bumi dan Bangunan. Adanya sosialisasi perlu dilakukan untuk menggerakan kepatuhan dan kesadaran para wajib pajak agar patuh akan kewajibannya dalam membayar pajak. Sehingga wajib pajak sadar dan patuh akan kewajibannya dalam hal membayar pajak, khususnya Pajak Bumi dan Bangunan (PBB). Demi terciptanya pembangunan nasional yang merata dan berkesinambungan.

Dengan adanya program sosialisasi yang dilaksanakan oleh Pemerintah Desa Kliwonan akan menamba pengetahuan pajak bagi wajib pajak. Menurut Saad (2014: 1069) pengetahuan pajak dan kompleksitas yang dirasakan dari sistem pajak dipandang sebagai faktor yang berkontribusi terhadap perilaku ketidak patuhan di antara wajib pajak.

Setianto (2010: 30) menjelaskan sosialisasi adalah suatu proses di mana orang-orang mempelajari sistem norma, nilai, dan pola perilaku yang diharapkan oleh kelompok sebagai bentuk perubahan dari orang yang ikut dalam kegiatan tersebut. Sosialisasi perpajakan memberikan pengertian, wawasan, informasi, dan pembinaan kepada masyarakat dan wajib pajak pada khususnya. Dengan tujuan agar mengetahui tentang segala hal mengenai perpajakan dan undangundang perpajakan yang dilakukan oleh Dirjen Pajak maupun instansi lain yang berwenang.

Sosialisasi merupakan proses pembelajaran seumur hidup (Weidman, Twale, \& Stein, 2001: 1-12) dimana individu mendapatkan pengetahuan, keterampilan, dan nilai-nilai yang diperlukan untuk meningkatkan pengetahuan. Sosialisasi dapat mencakup berbagai komponen atau taktik, seperti orientasi formal dan informal, pendampingan, peluang dan jaringan sosial, dan refleksi kritis yang relevan untuk meningkatkan pengetahuan masyarakat.
Hasil penelitian Binambuni (2013: 78-87) dapat diambil kesimpulan bahwa sosialisasi PBB berpengaruh terhadap kepatuhan wajib pajak dalam membayar Pajak Bumi dan Bangunan (PBB). Terdapat hubungan yang erat antara sosialisasi pajak bumi yang dilakukan oleh pemerintah dalam hal ini yang dilakukan oleh aparat desa dengan kepatuhan dalam membayar Pajak Bumi dan Bangunan (PBB) oleh wajib pajak. Lebih lanjut, hasil penelitian Putra, Handayani, dan Topowijono (2014) juga menyatakan bahwa sosialisasi perpajakan berpengaruh positif dan signifikan terhadap kepatuhan wajib pajak orang pribadi dalam melakukan penyampaian SPT Tahunan di Kantor Pelayanan Pajak Pratama Singosari. Hal ini menunjukkan bahwa jika semakin tinggi intensitas sosialisasi yang dilakukan dibidang perpajakan orang, maka kepatuhan wajib pajak orang pribadi cenderung meningkat. 5. Mendatangi Langsung Wajib Pajak

Strategi merupakan seni dan sains dari tindakan yang diinformasikan untuk mencapai visi yang spesifik dan tujuan yang menyeluruh (Daniell, 2004: xiv-v). Sedangkan Chandler dalam Akdon (2011: 12) menyatakan bahwa strategi merupakan alat untuk mencapai suatu tujuan organisasi dalam kaitannya dengan tujuan jangka panjang. Dengan kata lain, strategi adalah pilihan dan rute yang tidak hanya sekedar mencapai suatu tujuan akan tetapi strategi juga dimaksudkan untuk mempertahankan keberlangsungan organisasi di dalam lingkungan hidup di mana organisasi tersebut menjalankan aktivitasnya.

Program yang dilaksanakan oleh Pemerintah Desa Kliwonan sebuah pelayanan kepada wajib pajak menurut Alm. J, et al. (2010: 57) bahwa layanan bantuan informasi wajib pajak yang disediakan oleh lembaga atau penanggung jawab pengumpul pajak memiliki dampak positif dan signifikan pada kecenderungan perilaku kepatuhan wajib pajak dalam membayar pajak.

Pemerintah Desa Kliwonan merupakan 
suatu organisasi di lingkup yang kecil di bawah kecamatan untuk menjaga eksistensinya di masyarakat strategi yang digunakan oleh pemerintah Desa Kliwonan dalam mencapai target pencapaian pembayaran Pajak Bumi dan Bangunan (PBB) adalah dengan mendatangi langsung wajib pajak.

Mendatangi langsung wajib pajak

\section{SIMPULAN}

Strategi Pemerintah Desa Kliwonan dalam peningkatan kesadaran masyarakat membayaran Pajak Bumi dan Bangunan di wujudkan dalam berbagai kegiatan yang peruntukan untuk masyarakat wajib pajak. Secara umum, terdapat 5 kegiatan inti yang dilakukan sebagai wujud strategi

\section{DAFTAR RUJUKAN}

Akdon. (2011). Manajemen strategik untuk manajemen pendidikan. Bandung. Alfabeta.

Alm, J., et al. (2010). Taxpayer Information Assistance Services and Tax Compliance Behavior. Journal of Economic Psychology. 31: 457-586.

Ansori, M. (2017). Tunggakan PBB Capai Miliaran, Kecamatan Banyuurip dan Purwodadi Paling Tidak Tertib. 15 Agustus 2017. Tersedia Online: http://purworejo.sorot.co/berita6108-tunggakan-pbb-capai-miliarankecamatan-banyuurip-dan-purwodadipaling-tidak-tertib.html. Diakses 8 September 2017.

Binambuni, D. (2013). Sosialisasi PBB pengaruhnya terhadap kepatuhan wajib pajak di desa Karatung Kecamatan Nanusa Kabupaten Talaud. Jurnal EMBA. 1 (4). 2078-2087.

Branson, S. Margaret. (1999). Belajar Civic Education dari Amerika. Yogyakarta. LkiS.

Bucek, J. (2017). Why and When Countries Implement Local Public Administration Reforms: ALong-Term View of Reform Dynamics in Slovakia, 1990-2015. Silva, C. N. \& Bucek, J. (Eds), Local merupakan strategi yang cukup efektif karena petugas pemungut pajak bisa langsung berinteraksi dengan wajib pajak. Bagi wajib pajak yang di datangi belum bisa membayar, petugas pemungut pajak bisa mengetahui kendala yang dialami wajib pajak sehingga belum bisa membayarkan Pajak Bumi dan Bangunan (PBB).

Pemerintah Desa Kliwonan yaitu; Pertama, bekerja sama dengan Pemerintah Kecamatan Banyuurip. Kedua, mengoptimalkan Seluruh Perangkat Desa. Ketiga, menggerakan Tim Pengerak PKK dan Dasawisma,. Keempat, melaksanakan Sosialisasi. Kelima, mendatangi Langsung Wajib Pajak.

Government and Urban Governance in Europe (pp. 33-70). Switzerland. Springer.

Clutterbuck, D. (2007). Coaching the Team at Work. London. Nicholas Brealey International.

Daniell, M. (2004). STRATEGY: A stepby-step approach to the development and presentation of world class business strategy. New York. Palgrave Macmillan.

Gabrillian, A. (2017). Pejabat Ditjen Pajak Didakwa Terima Suap Rp 1,9 Miliar. 10 Agustus 2017. Tersedia Online: http://nasional.kompas.com/ $\operatorname{read} / 2017 / 04 / 12 / 12314801 /$ pejabat. ditjen.pajak.didakwa.terima.suap. rp.1.9.miliar.

Heifetz, R. \& Linsky, M. (2002). Leadership on the Line: Staying Alive Through the Dangers of Leading. Boston, MA. Harvard Business School Press.

Isett, K. R., et al. (2011). Networks in public administration scholarship: understanding where we are and where we need to go. Public Adm Res Theory, 21(1). 157-173.

Isnanto, A. (2014). Standat pengajuan pajak bumi dan bangunan. Yogyakarta. 
Bahari press.

Jimenez, P. \&Iyer, G. S. (2016). Tax compliance in a social setting: The influence of social norms, trust in government, and perceived fairness on taxpayer compliance. Advances in Accounting. 34: 17-26.

Kementrian Keuangan Republik Indonesia. (2017). Optimalisasi Pendapatan Negara. Tersedia Online: https://www. kemenkeu.go.id/apbn2017 diakses pada hari sabtu 11 November 2017.

Kementrian Keuangan. (2016). Informasi APBN 2016.Direktorat Penyusunan APBN, Direktorat Jenderal Anggaran. Tersedia Online: https://www. kemenkeu.go.id/sites/default/files/ bibfinal.pdfdiakses pada hari sabtu 11 November 2017.

Lestari, F.F. (2017). Analisis Penerimaan Pajak Bumi dan Bangunan Perdesaan dan Perkotaan (PBB-P2) di Kabupaten Purworejo (studi kasus tahun anggaran 2013-2016). Surakarta. Univeritas Sebelas Maret.

Moleong, L. J. (2007). Metodologi penelitian kualitatif. Bandung. PT. Remaja Rosdakarya.

Muljono, D. (2010). Hukum pajak: konsep, aplikasi, dan penuntun praktis. Yogyakarta. CV. Andi Offset.

Primadhyta, S. (2016).Penerimaan Pajak Belum juga Tembus Separuh dari Target 2016. Tersedia Online:https:// www.cnnindonesia.com/ekono $\mathrm{mi} / 20160915163212-78-158578 /$ penerimaan-pajak-belum-juga-tembusseparuh-dari-target-2016/

Putra, R. R. R., Handayani, S. R., dan Topowijono. (2014). Pengaruh sanksi administrasi sosialisasi perpajakan dan kesadaran wajib pajak terhadap kepatuhan penyampaian SPT tahunan wajib pajak orang pribadi (Studi di Kantor Pelayanan Pajak Pratama Singosari, Kabupaten Malang). Jurnal e-Perpajakan, 1 (1), 1-10.

Rantung, J. F., Mandey, J., dan Londa, V.
Y. (2014). Peranan pemberdayaan kesejahteraan keluarga (PKK) dalam menggerakkan partisipasi masyarakat desa (suatu studi di desa Ongkau I Kabupaten Minahasa Selatan). Jurnal Administrasi Publik, 4 (5), 1-11.

Riana, N. R., Sjamsuddin, S., dan Hayat, A. (2014). Pelaksanaan peran TIM penggerak Pemberdayaan dan Kesejahteraan Keluarga (PKK) dalam memberdayakan perempuan (Studi tentang Program Pendidikan dan Keterampilan di Kecamatan Kaliori, Kabupaten Rembang). Jurnal Administrasi Publik, 2 (5), 851-856.

Saad, N. (2014). Tax Knowledge, Tax Complexity and Tax Compliance: Taxpayers' View. Procedia-Social and Behavioral Sciences, (109): 1069-1075.

Setianto. (2010). Pengaruh sosialisasi perpajakan dan pelaksanaan self assessment system terhadap tingkat kesadaran dan kepatuhan wajib pajak pada kantor pelayanan pajak Jakarta Cilandak. Jakarta. Universitas Pembangunan Nasional Vetran.

Supadmi, N, L. (2009). Meningkatkan kepatuhan wajib pajak melalui Kualitas pelayanan. Jurnal Ilmiah Akuntansi dan Bisnis. Vol.4, No.2. halaman 1-14.

Wafiyah. (2015). Pemberdayaan Dasa Wisma sebagai upaya pemberlangsungan K3 (kebersihan, keindahan, dan ketertiban) di dusun gintungan, desa deyangan, Kec.Mertoyudan, Kab.Magelang. DIMAS, 15 (1), 145-174.

Wati, I., Suntoro, I., dan Yanzi, H. (2015). Peranan PKK dalam meningkatkan pemberdayaan wanita Kelurahan Endang Rejo Kecamatan Seputih Agung. Jurnal Kultur Demokrasi, 3 (3), 1-12.

Weidman, J. C., Twale, D. J., \& Stein, E. L. (2001). Socialization of graduate and professional students in higher education: A perilous passage?. San Francisco. Jossey-Bass. 